\title{
Results of Primary Treatment with Bromocriptine of Prolactinomas with Extrasellar Extension
}

\author{
Johanna W. van't Verlaat, Ronald J.M. Croughs, Martin J. Hendriks and Nicolaas J. Bosma
}

\begin{abstract}
Nineteen patients, seven women and twelve men, with macroprolactinomas characterized by extrasellar extension and basal prolactin levels above $6 \mathrm{U} / \mathrm{l}$ were treated with $10-20 \mathrm{mg}$ bromocriptine daily in four divided doses for a mean period of 3.4 years (range 1.5-5.5 years). Plasma prolactin levels fell dramatically in all patients and values in the low normal range were obtained in sixteen patients. Tumor size was reduced by more than $75 \%$ in seventeen patients and by $50-75 \%$ in two patients. Tumor reduction was associated with the development of a partial empty sella in fourteen cases. In seventeen cases the pituitary became visible. Diminished visual acuity (six patients), bitemporal hemianopia (nine patients), unilateral and bilateral central scotomas (three patients) and oculomotor palsy (two patients) improved or normalized in all cases. Hypogonadism (all patients), hypothyroidism (nine patients) and hypocorticism (four patients) improved or normalized in most cases. It is concluded that in the medical treatment of macroprolactinomas $10-20 \mathrm{mg}$ bromocriptine in four divided doses effectively reduces both plasma prolactin level and tumor size. The good results in this study may be related to the continued use of a fixed dose regimen of bromocriptine regardless of the plasma prolactin lowering effect.

RÉSUMÉ: Résultats du traitement primaire par la bromocriptine des prolactinomes avec extension extrasellaire Dix-neuf patients, septs et douze hommes, porteurs de macroprolactinomes caractérisés par une extension extrasellaire et des taux de prolactine plasmatique de base supérieurs à $6 \mathrm{U} / \mathrm{L}$ ont été traités avec $10-20 \mathrm{mg}$ de Bromocriptine par jour en quatre doses séparées pendant une durée moyenne de 3.4 années (écart de 1.5 à 5.5 années). Les taux de prolactine plasmatique ont baissé de façon marquée chez tous les patients et des valeurs proches de la normale basse ont été obtenues chez 16 patients. La taille de la tumeur était réduite de plus de $75 \%$ chez dix-sept patients et de $50-75 \%$ chez deux patients. La réduction du volume tumoral était associée avec l'apparition d'une selle partiellement vide dans quatorze cas. Dans dix-sept cas, l'hypophyse normale devenait visible. L'acuité visuelle abaissée (6 patients), l'hémianopsie bitemporale ( 9 patients), des scotomes centraux uni ou bilatéraux ( 3 patients) et les paralysies oculo-motrices (2 patients) furent améliorés ou se normalisèront dans tous les cas. L'hypogonadisme (tous les patients), l'hypothyroïdie ( 9 patients) et l'hypocorticisme (4 patients) se sont améliorés ou normalisés dans la plupart des cas. Les auteurs concluent que dans le traitement médical des macroprolactinomes, $10-20 \mathrm{mg}$ de de bromocriptine en quatre doses séparées réduit efficacement et la taille tumorale et le taux plasmatique de prolactine. Les bons résultats observés dans cette étude pourraient être reliés à l'utilisation continue d'une zone prédéterminée de bromocriptine, quel que soit son effet réducteur du taux de prolactine sérique.
\end{abstract}

Can. J. Neurol. Sci. 1990; 17:71-73

Therapy of prolactin secreting microadenomas has been successful in $80-90 \%$ of patients treated by either transsphenoidal surgeryl or medical therapy with dopamine agonists particularly bromocriptine. ${ }^{2}$ In prolactin secreting macroadenomas surgical cure rate diminishes with increasing tumor size and prolactin level. ${ }^{3}$ Medical therapy with bromocriptine has been found to shrink most macroprolactinomas concomitant with a decrease of plasma prolactin levels. ${ }^{4}$ In a multicenter study Molitch et al ${ }^{5}$ present a systematic evaluation of the effectiveness of bromocriptine as primary therapy for macroprolactinomas in a group of 27 patients followed for a period of 6-15 months. The present study describes the results of a similar study from one center using a fixed dose of bromocriptine in 19 patients who have been followed-up for a mean period of 3.4 years.

\section{Clinical Material and Methods}

The study was carried out on 19 consecutive patients ( 7 women and 12 men) who were referred to our institution between 1982 and 1986 with untreated macroprolactinomas. All patients had radiological evidence of extrasellar extension of the tumor and basal plasma prolactin levels were more than $6 \mathrm{U} / \mathrm{l}$.

From the Departments of Neurosurgery (J.W.v.V., N.J.B.), Endocrinology (R.J.M.C.) and Radiology (M.J.H.), University Hospital Utrecht, The Netherlands

Reprint requests to: J.W. van't Verlaat, Department of Neurosurgery, University Hospital Utrecht, Aristoteleslaan I, 3707 E J Zeist, The Netherlands 
The patients were treated with $10 \mathrm{mg}$ bromocriptine daily given in four divided doses. The dose of bromocriptine was increased to $20 \mathrm{mg}$ daily if the plasma prolactin level had not normalized after three months of treatment.

Radiological assessment of the tumor included a high resolution CT scan using a Phillips 350 . Tumor reduction was expressed semiquantitatively as follows: no reduction in tumor size $(0)$, up to $50 \%$ reduction $(+), 50-75 \%$ reduction $(++)$ and more than $75 \%$ reduction $(+++)$.

Ophthalmological examination included measurement of visual acuity, fundoscopy and Goldmann perimetry.

Hormonal studies included base line plasma prolactin levels, determined by averaging three measurements in blood samples taken on different days at 08:00 $\mathrm{h}$ (fasting), gonadal, thyroidal and adrenocortical functions. Hormone measurements were performed using standard radioimmunossay techniques. Prolactin values are expressed as U/1 (1 IU MRC 81/541:25 $\mu \mathrm{g}$ ). Normal plasma prolactin values are $0.48 \mathrm{U} / 1$ for men and $0.60 \mathrm{U} / \mathrm{l}$ for women.

\section{RESULTS}

\section{Prolactin Levels}

Basal plasma prolactin levels ranged from 7 to $210 \mathrm{U} / \mathrm{l}$ (Table 1). During bromocriptine therapy ( $10 \mathrm{mg}$ daily) prolactin levels fell dramatically in all patients. Within three months values in the low normal range were obtained in 15 patients. Four patients with elevated plasma prolactin levels were given $20 \mathrm{mg}$ bromocriptine daily. Two of these patients still have slightly elevated plasma prolactin levels at the end of observation period (no 11,16 , see table).

\section{Radiology}

In 17 patients tumor size was reduced by more than $75 \%$ and in 2 patients by $50-75 \%$. Tumor reduction was associated with the development of a partial empty sella in 14 cases. In 17 cases the pituitary became visible.

\section{Ophthalmology}

Before treatment 6 patients had diminished visual acuity, 9 patients had bitemporal hemianopia, 3 patients had uni- or bilateral central scotomas and 2 patients had oculomotor palsy. During treatment, 1 patient kept diminished visual acuity in one eye and temporal hemianopia in the same eye. In this eye optic disc atrophy was seen before treatment. All other visual disturbances normalized during treatment.

\section{Hormonal Studies}

Hypothyroidism defined as a subnormal free thyroxine index was found in 9 patients. A free thyroxine index within the normal range was found in all of them during bromocriptine therapy. One patient was temporarily treated with 1-thyroxine as overt hypothyroidism was present. A basal plasma cortisol $\leq 0.30 \mu \mathrm{mol} / \mathrm{l}$ at $08: 00 \mathrm{~h}$ was found in 4 patients, and the response to insulin induced hypoglycaemia was negligible; during bromocriptine treatment basal plasma cortisol levels were in the normal range in these 4 patients and a normal response to insulin stimulation was found in 2 of them. Before treatment basal plasma testosterone levels in men were subnormal in all but 1 patient; during treatment normal values were found in 9 (out of 12) men.

\section{Clinical Symptoms}

Galactorrhoea was present in 1 female patient and disappeared during bromocriptine treatment. All females were amenorrhoeic at the time of diagnosis. Menstrual cycles returned in patients younger than 50 years.

Libido and potency were reduced in all 12 male patients before bromocriptine therapy. During treatment sexual libido and potency improved in all treated men, despite subnormal plasma testosterone levels in 3 men.

\section{Discussion}

The present prospective study confirms the effectiveness of the administration of the dopamine agonist bromocriptine as pri-

\begin{tabular}{|c|c|c|c|c|c|c|}
\hline patient (no) & pre-treatment & $\begin{array}{l}\text { plasma prolactin } \\
\text { at three months }\end{array}$ & $\begin{array}{c}\text { (U/l) at end of } \\
\text { observation }\end{array}$ & $\begin{array}{c}\text { period of } \\
\text { observation }(\mathbf{y r})\end{array}$ & $\begin{array}{c}\text { final dose of } \\
\text { bromocriptine (mg) }\end{array}$ & $\begin{array}{c}\text { tumor size } \\
\text { reduction }\end{array}$ \\
\hline 1 & 15 & 0.09 & 0.09 & 3.5 & 10 & +++ \\
\hline 2 & 109 & 0.21 & 0.07 & 1.5 & 10 & +++ \\
\hline 3 & 43 & 0.09 & 0.01 & 4.0 & 10 & +++ \\
\hline 4 & 12 & 0.01 & 0.01 & 2.5 & 10 & +++ \\
\hline 5 & 31 & 0.05 & 0.05 & 5.0 & 10 & +++ \\
\hline 6 & 110 & 0.07 & 0.04 & 1.5 & 10 & +++ \\
\hline 7 & 18 & 0.57 & 0.25 & 2.0 & 10 & +++ \\
\hline 8 & 14 & 0.37 & 0.09 & 3.0 & 10 & +++ \\
\hline 9 & 15 & 0.01 & 0.01 & 2.0 & 10 & +++ \\
\hline 10 & 70 & 0.71 & 0.28 & 1.5 & 20 & +++ \\
\hline 11 & 59 & 9.00 & 2.40 & 1.5 & 20 & ++ \\
\hline 12 & 7 & 0.06 & 0.01 & 5.0 & 10 & +++ \\
\hline 13 & 90 & 0.38 & 0.27 & 2.0 & 10 & +++ \\
\hline 14 & 21 & 0.01 & 0.01 & 4.5 & 10 & ++ \\
\hline 15 & 112 & 0.12 & 0.01 & 5.0 & 10 & +++ \\
\hline 16 & 182 & 5.45 & 0.74 & 5.0 & 20 & +++ \\
\hline 17 & 181 & 7.00 & 0.24 & 5.0 & 20 & +++ \\
\hline 18 & 80 & 0.10 & 0.02 & 4.5 & 10 & +++ \\
\hline 19 & 210 & 0.12 & 0.01 & 5.5 & 10 & +++ \\
\hline
\end{tabular}


mary therapy for large prolactinomas with extrasellar extension. The results in this series of 19 consecutive patients referred to a single center are even better than the results reported previously.6,7 Plasma prolactin levels decreased to normal levels in 17 patients and from extremely elevated to only slightly elevated in the other 2 patients. Tumor size was reduced by more than $75 \%$ in 17 patients and by $50-75 \%$ in 2 patients. Molitch et al $^{5}$ performed a prospective multicenter study on the effect of bromocriptine therapy in 27 evaluable patients with macroprolactinomas. Tumor size was reduced by more than $50 \%$ in 13 of the 27 patients and plasma prolactin levels normalized in 18 of the 27 patients. Possible reasons for the better results in our series compared to the results obtained by Molitch et $a^{5}$ are a standardized dose and regimen of bromocriptine regardless of the plasma prolactin lowering effect and a longer observation period. Our patients were treated with a fixed dose of $10 \mathrm{mg}$ bromocriptine daily in four divided doses of $2.5 \mathrm{mg}$. On this regimen given for three months plasma prolactin levels decreased to normal in 15 patients and the same dose of bromocriptine was continued. In the other 4 patients the dose of bromocriptine was increased to $20 \mathrm{mg}$ also given in four divided doses given during the day. Using the regimen plasma prolactin values normalized in 2 cases and remained slightly elevated in 2 other cases. The patients reported by Molitch et al ${ }^{5}$ were treated with 5 to $12.5 \mathrm{mg}$ bromocriptine daily in a non-standardized way for a period of $6-15$ months. Liuzzi et al ${ }^{8}$ report tumor reduction in 29 of 38 patients with macroprolactinomas treated in a non-standardized way with 5 to $20 \mathrm{mg}$ bromocriptine daily for a period of two years. The observation period in our study varied from 1.5 to 5.5 years, but most patients were followed for more than 3 years. Thus, to obtain optimal results of bromocriptine therapy in macroprolactinomas it might be important to prescribe bromocriptine in a standardized way independent of the plasma prolactin lowering effect and to evaluate the results only after several years of therapy. The excellent results obtained in all 19 patients in this series confirm that therapy with bromocriptine should be considered as initial management of patients with macroprolactinomas. Primary surgical treatment is not as effective as bromocriptine in lowering prolactin levels and in preservation or restoration of anterior pituitary functions. $9,10,11$
From our data it is suggested that a fixed schedule of bromocriptine of at least $10 \mathrm{mg}$ daily given in four divided doses is superior to a schedule based on the plasma prolactin lowering effect of bromocriptine. To continue bromocriptine therapy indefinitely once a major tumor shrinkage has occurred and hormonal function is normalized seems an acceptable approach at present.

\section{REFERENCES}

1. Hardy J, Beauregard H, Robert F. Prolactin secreting pituitary adenomas, transsphenoidal microsurgical treatment. Clin Neurosurg $1980 ; 27: 38-47$

2. Grossman A, Besser GM. Prolactinomas. Br Med J 1985; 290: 182 184.

3. Randall RV, Laws ER, Abboud CF, et al. Transsphenoidal microsurgical treatment of prolactin-producing pituitary adenomas, results in 100 patients. Mayo Clin Proc 1983; 58: 108-121.

4. Vance ML, Evans WS, Thorner MO. Diagnosis and treatment, drugs five years later, bromocriptine. Ann Intern Med 1984; 100: 78-91.

5. Molitch ME, Elton RL, Blackwell RE, et al. The bromocriptine study group, bromocriptine as primary therapy for prolactinsecreting macroadenomas, results of a prospective multicenter study. J Clin Endocrinol Metab 1985; 60: 698-705.

6. Scotti G, Scialfa G, Pieralli S, et al. Macroprolactinomas. CT evaluation of reduction of tumor size after medical treatment. Neuroradiology 1982; 23: 123-126.

7. Wass JAH, Williams J, Charlesworth $M$, et al. Bromocriptine in management of large pituitary tumors. Br Med J 1982; 284: 1908-1911.

8. Liuzzi A, Dallabonzana D, Oppizzi G, et al. Low doses of dopamine agonists in the long-tern treatment of macroprolactinomas. N Engl J Med 1985; 313: 656-659.

9. Aubörg PR, Derome PJ, Peillon F, et al. Endocrine outcome after transsphenoidal adenomectomy for prolactinoma, prolactin levels and tumor size as predicting factors. Surg Neurol 1980; 14 : 141-143.

10. Rawe SE, Williamson HO, Levine JH, et al. Prolactinomas, surgical therapy, indications and results. Surg Neurol 1980; 14: 161. 167.

11. Faria MA, Tindall GT. Transsphenoidal microsurgery for prolactinsecreting pituitary adenomas. J Neurosurg 1982; 56: 33-43. 